Etnográfica

Revista do Centro em Rede de Investigação em

Antropologia

vol. $12(2) \mid 2008$

Vol. $12(2)$

\title{
O corpo, o gueto e o Estado penal: entrevista com Loïc Wacquant
}

Por Susana Durão

\section{Susana Durão e Loïc Wacquant}

\section{(2) OpenEdition}

Journals

Edição electrónica

URL: https://journals.openedition.org/etnografica/1811

DOI: 10.4000/etnografica. 1811

ISSN: 2182-2891

Editora

Centro em Rede de Investigação em Antropologia

Edição impressa

Data de publição: 1 novembre 2008

Paginação: 455-486

ISSN: 0873-6561

Refêrencia eletrónica

Susana Durão e Loïc Wacquant, «O corpo, o gueto e o Estado penal: entrevista com Loïc Wacquant», Etnográfica [Online], vol. 12 (2) | 2008, posto online no dia 05 julho 2012, consultado o 10 fevereiro 2022. URL: http://journals.openedition.org/etnografica/1811 ; DOI: https://doi.org/10.4000/ etnografica. 1811

\section{(c) (i) (9)}

Etnográfica is licensed under a Creative Commons Attribution-NonCommercial 4.0 International License. 


\section{O corpo, o gueto e o Estado penal}

\section{Entrevista com Loüc Wacquant}

Por Susana Durão

Loïc Wacquant é professor de sociologia na University of California, em Berkeley e investigador do Centre de Sociologie Européenne, em Paris. Os seus interesses incluem a incorporação, a dominação etno-racial, a desigualdade urbana, a penalização e a teoria social. Em português tem publicados os livros Corpo e Alma. Notas Etnográficas de um Aprendiz de Boxe (Relume Dumará, 2002); O Mistério do Ministério. Pierre Bourdieu e a Política Democrática (Revan, 2005); Onda Punitiva. O Novo Governo da Insegurança Social (Revan, 2007) e As Duas Faces do Gueto (Boitempo, 2008). É co-fundador e editor da revista interdisciplinar Ethnography e foi colaborador regular do Le Monde diplomatique entre 1994 e 2004.

FOI EM LISBOA, NO QUADRO DA ETHNOGRAFEAST III, EM JUNHO DE 2007, que entrevistei Loïc Wacquant. Naquele momento o seu entusiasmo era partilhado por um colectivo de pessoas que discutia a dimensão pública da etnografia. Loïc Wacquant tem um percurso que deriva da sua reconhecida energia e dinamismo pessoal. A sua produção científica e pública é impressionante. Aliás, faz questão de sublinhar na sua vida essa dupla acção: a de cientista social e a de actor com voz na esfera pública. A maioria dos seus textos começa por ser publicada em França ou nos Estados Unidos da América, mas rapidamente vários deles são traduzidos e lidos nos cinco continentes do globo. Se fosse possível resumir a sua já extensa produção, diria o seguinte: as investigações sobre guetos negros norte-americanos e as banlieues francesas, o boxe como profissão do corpo, as prisões e os sistemas penais mundiais têm confluído para uma interessante e perturbante reflexão sobre a modernidade avançada e o Estado neoliberal. É de tudo isso que trata a entrevista que irão ler.

SUSANA DURÃO Gostaria de aproveitar a sua presença em Lisboa, no quadro destes estimulantes encontros da Ethnografeast III sobre "Etnografia e esfera 
pública" - que organizou com Manuela Ivone Cunha e Antónia Pedroso de Lima - para retraçar brevemente a história desta "festa", e também para que nos desse uma ideia do seu percurso académico tão singular.

LOÏC WACQUANT Estou muito feliz por Portugal acolher estes terceiros encontros da Ethnografeast, depois de Berkeley em 2002 e de Paris em 2004, organizados sob a égide da revista Ethnography. Como o seu nome indica, e em continuidade com a linha intelectual da revista, a Ethnografeast é uma espécie de celebração colectiva da etnografia, levada a cabo por aqueles que a ela se dedicam e cujo objectivo é simultaneamente lúdico, prático e científico. ${ }^{1}$ Trata-se, desde logo, de criar a "efeverscência colectiva", como teria dito Émile Durkheim, para renovar as nossas energias e o nosso envolvimento no trabalho de terreno, e sobretudo encorajar os jovens investigadores a nela investir - é por isso que a edição de Lisboa consagra um dia completo aos trabalhos de doutorandos e de etnógrafos da nova geração.

É, além disso, a ocasião para activar o diálogo entre as disciplinas que praticam a etnografia (começando pela sociologia e antropologia, mas indo bastante mais além), mas também entre os diferentes géneros de etnografia, entre as tradições teóricas que a informam, entre as gerações e entre os continentes e os países: reunimos em Lisboa investigadores provenientes dos Estados Unidos, de França, de Itália, de Inglaterra, da Holanda, do Brasil, da África do Sul e, é claro, de Espanha e de Portugal... Alguns pensam que a etnografia está em crise, outros que ela está em pleno boom; uns vêem nela uma prática essencialmente hermenêutica e literária, outros um instrumento de prova científica ou de construção teórica, outros ainda uma forma da consciência colectiva nas sociedades contemporâneas - em suma, uma grande variedade de estilos e de posições vão confrontar-se. A ideia é abrir ao máximo a constelação dos debates e, deste ponto de vista, Manuela e Antónia, a quem será necessário atribuir todo o mérito por este encontro, preencheram magnificamente o caderno de encargos. Enfim, a Etnografeast tem por objectivo ajudar-nos a elaborar e a clarificar colectivamente os parâmetros e as missões da etnografia, tanto no mundo da ciência como no do debate cívico e político. É esse, aliás, o tema que anima os nossos encontros em Lisboa: "Etnografia e esfera pública".

\section{DO SUL DA FRANÇA AO PACÍFICO SUL}

SD Atentemos, então, no seu itinerário. Começou por ser aluno de Pierre Bourdieu, com quem trabalhou de seguida durante quase vinte anos. Poderá reconstituir o percurso pessoal e intelectual que o conduziu a encontrá-lo?

I Loïc Wacquant, 2003, "Ethnografeast: A progress report on the practice and promise of ethnography”, Ethnography, 4-1 (Março), pp. 1-10. 
LW Nasci no Sul da França, numa família da classe média intelectual e estudei na escola pública da minha aldeia e depois no grande liceu da cidade vizinha, Montpellier. De seguida fui para Paris onde, não sabendo muito bem que curso seguir, estudei então economia industrial. Entrei numa grande école de gestão, a École des HEC, ${ }^{2}$ em Paris, por defeito mais do que por vocação: não era suficientemente dado à matemática para ser atraído pela Polytechnique e não era suficientemente "literário" para encarar a École Normale Supérieure, tinha portanto escolhido um concurso cujo perfil ficava entre os dois. Tinha na ideia fazer economia política, mas desencantei-me rapidamente: a HEC é uma escola profissional que nos prepara para ser gestor numa grande empresa, e essa ideia horrorizava-me. Procurava então mudar de rumo e admitia fazer história social (um dos meus livros preferidos nesse momento era Louis XIV et vingt millions de français, um estudo tipo da École des Annales por Pierre Goubert) ${ }^{3}$ quando, uma noite, um amigo me levou a assistir a uma conferência de Pierre Bourdieu sobre o tema "Questões de política". Estávamos em Novembro de 1980, pouco depois da saída de Le Sens pratique e antes da sua nomeação para o Collège de France. ${ }^{4}$ Para mim esta conferência foi uma verdadeira revelação: não compreendi três quartos do que Bourdieu exprimia mas percebi bem que qualquer coisa de muito importante se dizia e que era necessário aprofundá-lo.

\section{SD Tinha que idade?}

LW Tinha vinte anos. Depois da conferência, tivemos uma discussão apaixonante com Bourdieu no bar dos estudantes até às quatro horas da manhã. Tive o sentimento muito vivo, ao ouvi-lo responder às perguntas que lhe fazíamos em todas as direcções, que, tal como um cirurgião, ele recortava o corpo da sociedade francesa para nos mostrar as entranhas e o funcionamento interno de uma maneira que eu nunca teria achado possível. Ao regressar dessa conferência de madrugada, disse-me: "Se isto é a sociologia, é isto que eu quero fazer." Mas se esta conferência marcou um começo, é sem dúvida porque eu tinha disposições nesse sentido, devido à minha trajectória familiar e pessoal. Tinha adquirido um olhar proto-sociológico, devido à mobilidade social dos meus pais, que tinha marcado fortemente a minha primeira infância, às oposições de classe na aldeia onde cresci, e também devido à minha mobilidade geográfica e regional. Sendo proveniente do Sul, habitar nos limites de Paris era quase ser expatriado! Contudo, no final, sou devedor da minha experiência na HEC, mesmo tendo-me aí aborrecido terrivelmente, uma vez que esta me colocou em

2 A École des HEC, École des Hautes Études Commerciales, é uma das mais prestigiadas grandes écoles francesas. Criada em 1881, depende da Chambre de Commerce et d'Industrie de Paris. (N. T.)

3 Pierre Goubert, Louis XIV et vingt millions de français (Paris, Hachette, 1967, reed. 1997).

4 Pierre Bourdieu, Le Sens pratique (Paris: Minuit, 1980); o tipo e o estilo de conferência pública que Bourdieu dava na época está bem captado em Questions de sociologie (Paris, Minuit, 1980). 
contacto com um mundo, o da empresa, em que descobri que não queria estar e de que fugi para ir para o universo da investigação. Depois a minha escolaridade neste campus colocou-me imensas questões e encaminhou-me indirectamente para a sociologia, pelo choque cultural frontal que era para mim o facto de me encontrar imerso no meio dos filhos da grande burguesia parisiense e da nobreza - que eu acreditava, ingenuamente, que tinha sido eliminada em 1789! O meu vizinho de quarto chamava-se Christian de Rivelrieux de Varax e tocava trombeta de caça [cor de chasse] à noite na nossa varanda comum, já está a ver...

Encorajado por este encontro com Bourdieu, iniciei, paralelamente aos meus estudos de economia industrial, um curso universitário em sociologia. Fiz o primeiro ciclo (licence) e depois o segundo (mestrado) em Nanterre - que ainda tinha na época o cognome de "Nanterre vermelha" (Nanterre la rouge)! Participar nestes dois universos ao mesmo tempo, uma grande école, vocacionada para a perpetuação dos meios de negócios parisienses, e uma universidade pública, que era um laboratório histórico da subversão estudantil e da crítica social, era uma boa introdução prática à sociologia. No campus da HEC, era um estudante dissidente a vários títulos, político e pedagógico, rebelde relativamente ao endoutrinamento grosseiro a que se era submetido - lembro-me de citar La Reproduction e até Le Système des objets de Baudrillard, ${ }^{5}$ na disciplina de marketing para provocar o professor! Éramos um pequeno grupo onde se encontravam os raros alunos provenientes das classes popular e média e quase todos oriundos da província que, em geral, eram de esquerda, intelectuais e empenhados. Chamavam-nos les bolchos ${ }^{6}$ e nós, nós chamávamos aos portadores da ordem escolar e social estabelecida les fachos ${ }^{7}$. Era bastante divertido, com a excepção das eleições de 1981, em que as relações se tornaram fortemente crispadas...

\section{SD Como foi ter à Nova Caledónia e depois aos Estados Unidos?}

LW À saída da HEC, obtive uma bolsa doutoral para ir para os Estados Unidos, onde passei um ano de estudos em 1982-83 em Chapel Hill, na Universidade da Carolina do Norte. Foi lá que se confirmou a minha conversão da economia à sociologia. Li com voracidade (entre os meus livros favoritos, os de Elliot Liebow, John Dollard, C. Vann Woodward e Erving Goffman) e segui cursos de teoria sociológica e de sociologia histórica e comparada num departamento excelente, onde me liguei por amizade intelectual com Gerhard Lenski e Craig

5 Pierre Bourdieu e Jean-Claude Passeron, La Reproduction. Eléments d'une théorie du système d'enseignement (Paris, Minuit, 1970); Jean Baudrillard, Le Système des objets (Paris, Gallimard, 1968).

6 Les bolchos: os bolcheviques, em referência à sua pertença ao Partido Comunista ou à esquerda radical. (N.T.)

7 Les fachos, nome familiar francês para partidário do fascismo. (N.T.) 
Calhoun, que me encorajaram na minha transformação. Todas as quintas-feiras, durante um semestre, almoçava no seu gabinete com Lenski (o autor do clássico Power and Privilege) e conversávamos por diversas vezes sobre teoria e história. ${ }^{8}$ Seguidamente, parti por dois anos para a Nova Caledónia, em 1983-85, para aí fazer o meu serviço militar, mas no quadro de assistência técnica. Por uma sorte surpreendente, era um serviço civil enquanto sociólogo no centro de investigação do ORSTOM, o antigo "centro de investigação colonial" de França. Isto deu-me dois anos de formação prática na prática sociológica num contexto espinhoso e portanto particularmente instrutivo.

Em Nanterre, tinha feito "sociologia da cultura e da educação" e escrito uma dissertação de final de curso (mémoire de maîtrise) que misturava história e etnografia, baseada na minha experiência na HEC, que se intitulava "Produção escolar e reprodução social", portanto tinha certamente lido e utilizado os trabalhos de Pierre Bourdieu. Durante o meu último ano em Paris, escapava às minhas aulas da HEC para assistir ao seu curso do Collège de France. Depois de cada sessão, Bourdieu e eu caminhávamos juntos até casa dele a conversar - para mim, era como se fosse um curso particular acelerado! E quando parti para a Nova Caledónia iniciámos uma correspondência continuada; seguidamente, após o meu regresso, fui associado ao Centre de Sociologie Européenne como "membro expatriado".

Passei dois anos na Nova Caledónia, numa equipa muito pequena, pois éramos três investigadores, na altura da sublevação kanak de Novembro de 1984. Vivi assim e trabalhei numa sociedade colonial arcaica muito brutal, já que a Nova Caledónia, nos anos 1980, era uma colónia tipo do final do século XIX que tinha sobrevivido, quase intacta, até ao fim do século XX. Foi uma experiência social extraordinária para um aprendiz de sociólogo; tratava-se de realizar inquéritos sobre o sistema escolar, a urbanização e a mudança social neste contexto de insurreição, em estado de emergência, e de observar em tempo real as lutas entre colonos e independentistas, e de ter de reflectir concretamente sobre o papel cívico da ciência social. Participei assim num congresso à porta fechada da Frente de Libertação Nacional Kanak e Socialista em Canala, dei a volta à Grande Terre (a ilha principal) e passei vários dias em Lifou em casa de amigos militantes kanak quando praticamente ninguém circulava no território.

Foi então também que li os clássicos da etnologia, Mauss, Mead, Malinowski, Radcliffe-Brown, Bateson, etc. (especificamente os trabalhos sobre o Pacífico Sul: as ilhas Trobriands eram mesmo ao lado) e que mantive os meus primeiros cadernos de terreno (o primeiro de todos foi esboçado na tribo de Luecilla, na baía de Wé, por altura do Natal de 1983). E que publiquei os meus primeiros trabalhos, não verdadeiramente "de juventude" mas diríamos antes de

8 Gerhard Lenski, Power and Privilege: A Theory of Social Stratification (Chapel Hill, University of North Carolina, 1984, primeira edição 1968). 
infância. ${ }^{9}$ No final da minha estadia caledoniana, obtive uma bolsa de quatro anos para ir fazer o meu doutoramento na Universidade de Chicago, berço da sociologia norte-americana. Ao chegar à cidade de Upton Sinclair, a minha intenção era a de trabalhar numa antropologia histórica da dominação colonial na Nova Caledónia. Fui seguidamente desviado para a América.

\section{O GUETO, O GINÁSIO E A PERIFERIA}

SD É assim que um jovem investigador francês se vai confrontar com o gueto negro americano...

LW Na realidade, combinaram-se dois acontecimentos imprevistos. De um lado, a porta da Nova Caledónia fechou-se bruscamente: em Nouméa, um burocrata medíocre que me supervisionava tinha abusado da sua autoridade para co-assinar contra a minha vontade uma monografia sobre o sistema escolar que eu tinha realizado sozinho - o que, tristemente, era uma prática corrente no ORSTOM. ${ }^{10}$ Denunciei esta prevaricação intelectual junto da direcção do Instituto em Paris, que evidentemente se apressou a cobrir o fraudulento. Resultado, vi-me "impedido de permanecer" neste organismo e, por conseguinte, na ilha. Do outro lado, vi-me confrontado com o quotidiano da realidade do gueto de Chicago. Habitava nas imediações do bairro negro e pobre de Woodlawn e era um choque terrível ter sob a minha janela aquela paisagem urbana quase lunar, inverosímil de ruína, de miséria, de violência, com uma separação totalmente hermética entre o mundo branco, próspero e privilegiado da universidade e os bairros negros ao abandono em volta (o campus de Hyde Park está rodeado em três lados pelo gueto de South Side e no quarto pelo lago Michigan). Isso questionava-me profundamente no dia-a-dia. É então que intervém o segundo encontro decisivo da minha vida intelectual, aquele que tive com William Julius Wilson.

Wilson é o mais eminente sociólogo negro americano da segunda metade do século XX e o grande especialista da questão das relações entre "raça e classe" neste país. Propôs-me trabalhar com ele num projecto sobre pobreza urbana (em traços gerais, o programa de investigação traçado pelo seu livro

9 Loïc Wacquant, 1985, "La question scolaire en Nouvelle-Calédonie: idéologies et sociologie”, Les Temps modernes, 464 (Março), pp. 1654-1685; 1985, “Jeunesse, ordre coutumier et identité canaque en Nouvelle-Calédonie” (com J.M. Kohler e P. Pillon), Cahiers ORSTOM-Série Sciences Humaines, 21-2/3, pp. 203-228; 1986, "Communautés canaques et société coloniale: notes complémentaires sur la 'question canaque" ", Actes de la recherche en sciences sociales, 61 (Março), pp. 56-64; 1989, "The dark side of the classroom in New Caledonia: Ethnic and class segregation in Nouméa's primary school system”, Comparative Education Review, 33-2 (Maio), pp. 194-212.

10 Loïc Wacquant, 1985, L'École inégale. Éléments pour une sociologie de l'enseignement en Nouvelle-Calédonie (Nouméa e Paris, Editions de l’OrSTOM e Institut Culturel Mélanésien, 212 pp.). 
The Truly Disadvantaged) e rapidamente me tornei seu colaborador próximo e co-autor. ${ }^{11}$ Tive então a possibilidade de ir imediamente ao cerne do assunto e também de ver de perto como funcionava este debate científico e político ao mais alto nível, nomeadamente nas instituições filantrópicas e nos think tanks. É assim que desenvolvo as minhas investigações, primeiro com Wilson depois sozinho, sobre a transformação do gueto negro após os anos 1960, tentando sair da visão patologizante que impregna e envieza os trabalhos sobre a questão. ${ }^{12}$ Tenho uma grande dívida relativamente a Bill Wilson, que foi um mentor simultaneamente exigente e generoso: estimulou-me e apoiou-me, mas também me deu a liberdade de divergir das suas análises, por vezes de maneira frontal.

A etnografia desempenhou então um papel central, por duas razões. Por um lado, segui mais cursos de antropologia do que de sociologia, porque o departamento de sociologia de Chicago era intelectualmente muito pálido e porque eu estava visceralmente agarrado a uma concepção unitária da ciência social herdada da minha formação francesa. Os trabalhos e os encorajamentos ao trabalho de John e Jean Comaroff, de Marshall Sahlins, de Bernard Cohn e Raymond Smith levaram-me na direcção do trabalho de terreno. Por outro lado, quis rapidamente encontrar um ponto de observação directa no interior do gueto, porque a literatura existente sobre $\mathrm{o}$ assunto estava dominada pela abordagem estatística, desenvolvida a partir de muito alto, por investigadores que não têm qualquer conhecimento primário, ou até mesmo secundário, do que faz a

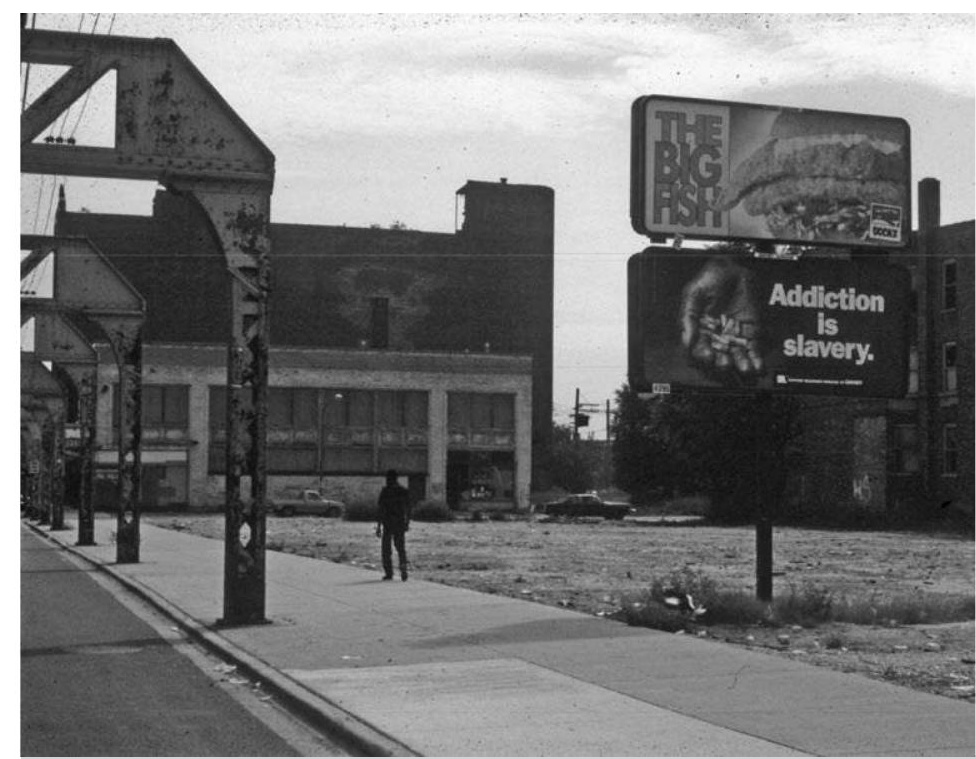

Paisagem do gueto de South Side, Chicago, nos anos 90.

11 William Julius Wilson, The Truly Disadvantaged: The Inner City, the Underclass, and Public Policy (Chicago, University of Chicago Press, 1987), obra que se segue a The Declining Significance of Race: Blacks and Changing American Institutions (Chicago, University of Chicago Press, 1978).

12 Loïc Wacquant, 1997, "Three pernicious premises in the study of the American ghetto", International Journal of Urban and Regional Research, 2 1-2 (Junho), pp. 341-353; trad. portuguesa abreviada: 1996, "Três premissas perniciosas no estudo do gueto norte-americano", Mana: Estudos de Antropologia Social, 2-2 (Outubro), pp. 145-161. 
realidade quotidiana dos bairros deserdados da cintura negra, e que preenchem este vazio com os estereótipos retirados do senso comum corrente, jornalístico ou universitário. Quis reconstruir a questão do gueto a partir de baixo, na base de uma observação precisa da vida quotidiana dos habitantes desta terra non grata mas também, por esta mesma razão, incognita. ${ }^{13}$

SD É esta sociologia "rente ao solo" que o levou a frequentar os ringues de boxe?

LW Considerava impossível, epistemologicamente e moralmente, trabalhar sobre o gueto sem o conhecer em primeira mão, dado que este estava ali, ao pé da minha porta (no Verão, ouviam-se claramente os tiros que estalavam na noite do outro lado da rua), e que os trabalhos estabelecidos me pareciam carregados de noções académicas improváveis e perniciosas, como o mito científico da underclass que ia então de vento em popa. ${ }^{14}$ Depois de algumas tentativas abortadas, encontrei por acidente um ginásio de boxe em Woodlawn, a três passos do meu apartamento, e inscrevi-me dizendo que desejava aprender boxe, muito simplesmente porque não havia mais nada a fazer no contexto. De facto, não tinha de todo qualquer curiosidade nem qualquer interesse pelo mundo do pugilismo em si. O ginásio devia apenas ser um ponto de observação no gueto, um lugar de encontro com informadores potenciais.

Mas muito depressa o ginásio $(\mathrm{gym})$ se revelou ser não somente uma muito bela janela sobre a vida quotidiana dos jovens do bairro, mas também um microcosmos complexo, com uma história, uma cultura, uma vida social, estética, emocional e moral em si muito intensa e muito rica. Liguei-me com uma amizade muito forte, carnal, com os habitués do ginásio e com o velho treinador, DeeDee Armour, que se tornou uma espécie de pai adoptivo. ${ }^{15}$ Gradualmente, fui atraído pelo magnetismo da Sweet Science, ao ponto de passar a maioria do meu tempo no ginásio. Ao fim de um ano tinha-se-me imposto a ideia de escavar um segundo assunto: a lógica social de um ofício do corpo. O que faz vibrar os boxeurs, porque se envolvem eles neste ofício tão duro e destruidor entre todos, como adquirem eles a vontade e as habilidades necessárias para durar? Qual é o papel do ginásio, da rua, da violência envolvente

13 Loïc Wacquant, 1992, “'The Zone': Le métier de 'hustler' dans le ghetto noir américain”, Actes de la recherche en sciences sociales, 93 (Junho), pp. 38-58; trad. portuguesa: “The Zone”, em Daniel Soáres Lins et al., Cultura e Subjetividade. Saberes Nômades (Campinas, Papirus, 1997), pp. 49-68.

14 Loïc Wacquant, 1996, L"underclass' urbaine dans l'imaginaire social et scientifique américain", em L'Exclusion: l'État des Savoirs, dir. Serge Paugam (Paris, Editions La Découverte), pp. 248-262; trad. portuguesa: 1997, “A 'underclass' urbana no imaginário social e científico norte-americano", Estudos Afro-Asiáticos, 31 (Outubro), pp. 37-50.

15 Loïc Wacquant, 2002, "Chicago Fade: remettre le corps du chercheur en scène”, Quasimodo, 7 (Primavera), pp. 171-179. 
e do desprezo racial, do interesse e do prazer, da crença colectiva na transcendência pessoal em tudo isto? Como se cria uma competência social que é uma competência incorporada, que se transmite através de uma pedagogia silenciosa dos organismos em acção? Em suma, como se fabrica e se manifesta o habitus pugilístico ${ }^{16}$

Foi assim que me vi a desenvolver dois projectos conexos, muito diferentes mas de facto estreitamente ligados: uma microssociologia carnal da aprendizagem do boxe como ofício do corpo subproletário no gueto, dando deste universo um "corte" particular visto a partir de baixo e do interior; e uma macrossociologia histórica e teórica do gueto como instrumento de fechamento racial e de dominação social, oferecendo uma perspectiva generalizante orientada para o exterior e para o alto.

SD É no momento em que conduz o seu trabalho de terreno sobre o South Side que explode o discurso-pânico sobre a "guetização" das periferias populares em França.

LW Precisamente. Em 1990, depois dos motins de Vaux-en-Velin, cristaliza-se em França - depois nos outros países europeus - um "pânico moral" em torno dos bairros periféricos desestabilizados pela desindustrialização e o desemprego em massa, de que se diz instantaneamente que se metamorfosearam em gueto à americana, com os imigrantes, em certa medida, no papel dos negros. Ora, estava em Chicago mergulhado no meu trabalho de campo no seio do South Side, e esta lenda mediática, rapidamente partilhada pelos políticos e por certos investigadores (nem sempre os mais bem informados!), parecia-me precisamente burlesca (ubuesque). Ainda sobre esta questão, nadava-se no meio de estereótipos e clichés, baseados neste caso numa dupla ignorância: a ignorância do que é a periferia popular francesa na era pós-fordista e a ignorância do gueto negro americano. O produto destas duas ignorâncias acumuladas era um discurso completamente desfasado relativamente à realidade, mas que exerceu imediatamente um poderoso efeito de "profecia auto-realizante", porque era retomado por todos e em todo o lado e rapidamente guiou as políticas públicas - e nomeadamente a política dita da cidade, com o anúncio periódico das "leis antigueto" tão hipócritas quanto ineficazes.

16 Loïc Wacquant, 1989, "Corps et âme: notes ethnographiques d'un apprenti-boxeur", Actes de la recherche en sciences sociales, 80 (Novembro), pp. 33-67; 1995, "Protection, discipline et honneur: une salle de boxe dans le ghetto américain”, Sociologie et sociétés, 27-1 (Primavera), pp. 75-89; 1995, "The pugilistic point of view: How boxers think and feel about their trade", Theory \& Society, 24-4 (Agosto), pp. 489-535; 1995, "Pugs at work: Bodily capital and bodily labor among professional boxers", Body \& Society, 1-1 (Março), pp. 65-94; 1998, “The prizefighter's three bodies”, Ethnos: Journal of Anthropology, 63-3 (Novembro), pp. 325-352; trad. portuguesa: "Os três corpos do boxeador profissional”, em Daniel Soáres Lins et al., A Dominação Masculina Revisitada (Campinas, Papirus, 1998), pp. 73-96. 
Considerei que tinha um dever simultaneamente científico e cívico de intervir neste (falso) debate para recusar os termos em que era feito, através do estudo metódico das transformações dos bairros de relegação, esses espaços estigmatizados para onde foram afastadas as populações marginalizadas, tanto sob o ângulo material como sob o ângulo da honra, nas duas margens do Atlântico.

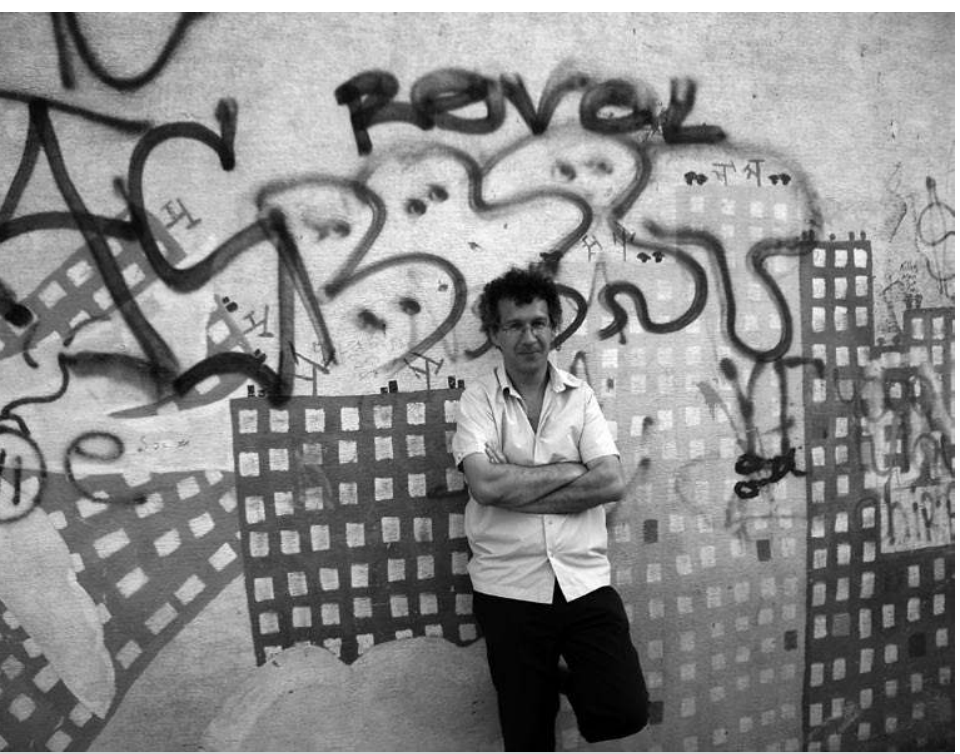

De regresso ao terreno da Cité des Quatre Mille, La Courneuve (Maio de 2006).

Desenvolvi então uma comparação, ponto por ponto, entre a evolução do gueto negro americano depois das grandes revoltas dos anos 1960 e a evolução das periferias populares em França depois de meados dos anos 1970, quer dizer durante a fase de desindustrialização, que deu, num primeiro momento, lugar a uma série de artigos orientados principalmente para o debate europeu. ${ }^{17}$ Para comparar o South Side de Chicago com a periferia parisiense, fiz um trabalho de terreno em 1989-91 na cité des Quatre Mille, na cidade de La Courneuve no nordeste de Paris, e nos corredores das administrações que levavam a cabo a chamada política de cidade. No final, este trabalho desemboca numa tripla clarificação, empírica, teórica e política: reconstituo como o "gueto comunitário" de meados do século XX se transformou em "hyperghetto" do lado americano; como os territórios operários da periferia urbana europeia entraram em decomposição, mas afastando-se do esquema do gueto, contrariamente ao discurso dominante, ao ponto de podermos caracterizá-los como antiguetos; e

17 Loïc Wacquant, 1992, "Banlieues françaises et ghetto noir américain: de l'amalgame à la comparaison", French Politics and Society, 10-4 (Outono), pp. 81-103; 1992, "Pour en finir avec le mythe des 'cités-ghettos': les différences entre la France et les Etats-Unis", Annales de la recherche urbaine, 52 (Setembro), pp. 20-30; 1992, "Décivilisation et démonisation: la mutation du ghetto noir américain", em L'Amérique des français, dir. Christine Fauré e Tom Bishop (Paris, Editions François Bourin), pp. 103-125; 1993, "Urban outcasts: Stigma and division in the black American ghetto and the French urban periphery", International Journal of Urban and Regional Research, 17-3 (Setembro), pp. 366-383; trad. portuguesa: "Proscritos da cidade: estigma e divisão social no gueto americano e na periferia urbana francesa”, Novos Estudos CEBRAP (São Paulo), 43, Novembro, 1995, pp. 64-83. 
demonstro que é o Estado que é o determinante maior das formas que toma a marginalidade urbana nos dois continentes. ${ }^{18}$

Enquanto desenvolvia o meu trabalho sobre o boxe e o gueto, estava em contacto permanente com Pierre Bourdieu, que me encorajou constantemente. Ele veio várias vezes a Chicago, onde visitou o ginásio e encontrou DeeDee e os meus amigos boxeurs. Foi por ocasião destas visitas que elaborámos o projecto de um livro que explicitaria o coração teórico do seu trabalho, visando na origem um público anglo-americano, visto que era nesta frente que as distorções e os obstáculos a uma apropriação frutuosa dos seus modelos eram mais fortes. Consagrámos três anos à redacção deste livro, intitulado An Invitation to Reflexive Sociology, ${ }^{19}$ que escrevemos directamente em inglês, e que rapidamente foi traduzido para francês e depois numa vintena de línguas. Sociologia do gueto, etnografia do corpo hábil, comparação transatlântica e trabalho teórico com Bourdieu: tudo se construiu em conjunto e ao mesmo tempo, e tudo encaixa.

\section{A ROCHA DO ESTADO PENAL}

SD Mas então como surgem as prisões neste programa de estudos?

LW Mais uma vez, como no caso da antropologia do pugilismo, foi totalmente imprevisto: foi a lógica da investigação e as surpresas do terreno que me forçaram a "entrar na prisão" - no sentido figurado, entenda-se. Ao elaborar a história de vida dos meus amigos boxeurs do ginásio de Woodlawn, apercebi-me de que todos tinham estado detidos. Verifiquei então que a prisão é uma instituição simultaneamente central e banal no horizonte das organizações com as quais os jovens do gueto se relacionam e que os faz tropeçar - como uma grande rocha no seu jardim pessoal, que não se pode retirar nem contornar, e que modifica toda a paisagem social.

Por exemplo, o meu amigo e companheiro de ringue Ashante tinha passado seis anos na prisão ao sair da adolescência; tinha, de resto, aprendido o boxe atrás das grades. À sua saída da penitenciária, encontrou refúgio no ginásio, que o protegeu da rua, e seguiu uma carreira de boxeur. Depois, quando a sua carreira no ringue se afundou e o ginásio fechou, recaiu na economia ilegal e reencontrou-se novamente sob os ferrolhos várias vezes. Ia periodicamente tirá-lo da prisão pagando a sua caução e o seu advogado... Ver o melhor amigo

18 Loïc Wacquant, 2006, "Ghetto, banlieues, État: réaffirmer la primauté du politique", Nouveaux regards, 33 (Abril-Junho), pp. 62-66; trad. portuguesa: em Fórum Sociológico (Lisboa), Outono 2006; 2008, "Ghettos and anti-ghettos: An anatomy of the new urban poverty", Thesis Eleven, 94, pp. 113 -118; trad. portuguesa em Cadernos de Ciências Sociais, no prelo.

19 Loïc Wacquant e Pierre Bourdieu, An Invitation to Reflexive Sociology (Chicago, University of Chicago Press, e Cambridge, UK, Polity Press, 1992). 
atirado para a prisão ao sair do tribunal é algo que nos seca existencialmente e intelectualmente! Foi esta experiência que me conduziu a fazer um trabalho de terreno piloto nas casas de detenção estado-unidenses em 1998-1999, em Los Angeles, depois em Chicago e Nova Iorque (com incursões no Brasil), para compreender o que acontecia. ${ }^{20} \mathrm{O}$ objectivo, aqui também, era o de fornecer os meios para furar o ecrã dos discursos dominantes sobre a prisão e as análises distantes e mecânicas da criminologia, que negligenciam a textura das relações carcerais no quotidiano: o emprisionamento representa antes de tudo o constrangimento dos corpos, e tudo o que isso imprime ao nível das categorias, dos desejos, do sentido de si e das relações com os outros.

$\mathrm{Na}$ realidade, não se pode compreender a trajectória do subproletariado negro americano depois dos motins que agitaram o gueto nos anos 1970 sem assumir no seu colimador analítico a expansão espantosa do Estado penal ao longo dos três últimos decénios do século. Entre 1975 e 2000, os Estados Unidos multiplicaram por cinco a sua população sob registo prisional (sous écrou) para se tornarem no líder mundial da encarceração com 2 milhões de detidos - coisa que eu ignorava então e de que não tinha qualquer registo analítico, como todos os sociólogos que trabalhavam sobre raça e classe na América (o primeiro a fazê-lo foi um jurista, Michael Tonry, em Malign Neglect, um livro-chave publicado em 1995, que atraiu a minha atenção porque eu queria utilizar este título para uma das minhas obras). ${ }^{21}$ Como se explica esta hiperinflação carceral? A primeira resposta, a da ideologia dominante e da investigação oficial, é dizer que ela está ligada ao crime. Mas a curva da criminalidade estagnou, entre 1973 e 1993, antes de cair fortemente, no preciso momento em que o emprisionamento levantava voo. Segundo mistério: enquanto que a proporção de negros em cada "coorte" de criminosos foi diminuindo durante vinte anos, a sua parte na população carceral não cessou de aumentar. Para resolver estes dois enigmas, é necessário sair do esquema "crime e castigo" e repensar a prisão como uma instituição política, uma componente central do Estado. Descobre-se então que o surgimento do Estado penal é o resultado de uma política de penalização da miséria, que responde ao crescimento da insegurança salarial e ao afundamento do gueto como mecanismo de controlo de uma população duplamente marginalizada no duplo plano material e simbólico. ${ }^{22}$

20 Loïc Wacquant, 2002 "The curious eclipse of prison ethnography in the age of mass incarceration", Ethnography, 3-4 (Inverno), n. ${ }^{\circ}$ especial "In and out of the belly of the beast", pp. 37 I-397; trad. portuguesa: "O curioso eclipse da etnografia prisional na era do encarceramento de massa", Discursos Sediciosos. Crime, Direito e Sociedade (Rio de Janeiro), 13, Outono 2003, pp. I 1-34.

21 Michael Tonry, Malign Neglect: Race and Punishment in America (Nova Iorque, Oxford University Press, 1995).

22 Loïc Wacquant, 1998, "Crime et châtiment en Amérique de Nixon à Clinton", Archives de politique criminelle, 20 (Primavera), pp. 123-138; trad. portuguesa: "Crime e castigo nos Estados [continua] 
SD E, como mostra em Les Prisons de la misère (1999), a expansão do Estado penal nos Estados Unidos está ela própria ligada à atrofia do Estado social... ${ }^{23}$

LW No momento em que mergulhava nas estatísticas penitenciárias para decifrar a espantosa ascenção do Estado penal na América, Clinton avalisava a welfare reform de 1996, elaborada pela facção mais reaccionária do partido republicano. A abolição do direito à assistência social para as mulheres desmunidas e a sua substituição pela obrigação ao assalariamento forçado (dito worfare) é um escândalo histórico, em todo o século XX, a medida mais regressiva tomada por um presidente que era suposto ser progressista. Por indignação política, escrevi um artigo no Le Monde diplomatique, depois um artigo mais aprofundado para uma revista de geografia política, a revista Hérodote. ${ }^{24}$ Ao analisar as implicações desta reforma, verifiquei que a atrofia organizada do sector social e a hipertrofia do sector penal do Estado americano eram não somente concomitantes e complementares, mas ainda que elas visavam a mesma população estigmatizada à margem do salariato. Tornava-se claro que a "mão invisível" do mercado desregulado apela para e necessita do reforço do "punho de ferro" da justiça criminal na base da estrutura de classes. ${ }^{25}$

Foi o que tentei mostrar em Les Prisons de la misère, ao seguir a difusão internacional da política de "tolerância zero" que é a ponta da lança da penalização da pobreza. Este livro foi rapidamente traduzido em três, seis, doze línguas, porque esta política de "contenção punitiva" das camadas precarizadas do novo proletariado urbano se difundiu por todo o planeta, na esteira do neoliberalismo económico. Foi assim que me desviei momentaneamente do gueto, levado pela urgência política e quase contra a minha vontade, para analisar

Unidos de Nixon a Clinton", Revista de Sociologia e Política (Curitiba), 13, Novembro 1999, pp. 39-50; Loïc Wacquant, 2000, “The new 'peculiar institution': On the prison as surrogate ghetto”, Theoretical Criminology, 4-3, n. ${ }^{\circ}$ especial sobre "New social studies of the prison", pp. 377-389; trad. portuguesa: "A nova 'instituçâo particular': a prisão como subsituto do gueto”, em Loïc Wacquant, Punir os Pobres (Rio de Janeiro, Freitas Bastos Editora, 2001), pp. 99-1 12; Loïc Wacquant, 2001, "Deadly symbiosis: When ghetto and prison meet and mesh”, Punishment \& Society, 3-1 (Inverno), pp. 95-133; trad. portuguesa: "A cor da justiça: quando gueto e prisão se encontram e se malham", em Loïc Wacquant e Daniel Lins (dirs.), Repensar os Estados Unidos (Campinas, Papirus, 2003), pp. 159-208.

23 Loïc Wacquant, Les Prisons de la misère (Paris, Editions du Seuil, 1999); trad. portuguesa: As Prisões da Miséria (Oeiras, Celta Editora, 2000; Rio de Janeiro, Jorge Zahar Editor, 2001).

24 Loïc Wacquant, 1997, "Les pauvres en pâture: la nouvelle politique de la misère en Amérique", Hérodote, 85 (Primavera), pp. 21-331; 1996, "De l'Etat charitable à l'Etat pénal: notes sur le traitement politique de la misère en Amérique”, Regards sociologiques, 11, pp. 30-38 (ambos traduzidos em português em Punir os Pobres, Rio de Janeiro, Revan, 2001); ver igualmente o número de Actes de la recherche en sciences sociales (124, Setembro 1998) consagrado à oscilação "De l'Etat social à l'Etat pénal", com artigos de David Garland, Katherine Beckett e Bruce Western, Dario Melossi e Loïc Wacquant. 25 Loïc Wacquant, Punishing the Poor: The Neoliberal Government of Social Insecurity (Durham e Londres, Duke University Press, 2008); trad. portuguesa: Onda Punitiva. O Novo Governo da Insegurança Social (Rio de Janeiro, Editora Revan, 2007). 
mais à frente as transformações das políticas penais nas suas relações com as políticas sociais.

SD Mas a análise do papel da prisão trá-lo aos bairros de relegação pois estes são o alvo privilegiado do desdobramento do Estado penal.

LW Com efeito, sem o planear, escrevi uma espécie de trilogia sobre as relações pobreza/etnicidade, Estado social e Estado penal na era do neoliberalismo triunfante, mas publicada desordenadamente. O primeiro volume é Parias urbains, onde, tendo refutado a tese da convergência transatlântica das formas de marginalidade urbana, formulo o diagnóstico da emergência de um novo regime de pobreza urbana, diferente do regime "fordista-keynesiano" que prevalecia até aos anos $1970 .{ }^{26}$ Chamo-lhe marginalidade avançada porque ela não é nem residual nem cíclica, mas está perante nós, inscrita no devir das sociedades avançadas submetidas às torções da desregulação capitalista. ${ }^{27}$ Sintetizando, a marginalidade avançada, que suplanta o gueto do lado americano e o território operário tradicional do lado europeu, é o produto da fragmentação do salariato, da desconexão funcional entre os bairros de relegação e a economia nacional e mundial, da estigmatização territorial e da retracção das protecções asseguradas pelo Estado social.

Como vai o Estado reagir ao crescimento desta marginalidade e gerir o cortejo de "problemas sociais" que ela carreia: desemprego, sem-abrigo, criminalidade, drogas, juventude desocupada e enraivecida, exclusão escolar, dissolução familiar e social, etc. Como conter as suas repercussões e, ao mesmo tempo, incitar as camadas precárias do novo proletariado urbano, aquilo a que se chama o "precariado", a aceitar os empregos instáveis e subpagos da economia desregulada dos serviços? A resposta é dada no segundo volume: Punishing the Poor disseca a invenção de um "novo governo da insegurança social", que alia a disciplina do workfare e o constrangimento de um aparelho policial e penal sobredimensionado e hiperactivo. Em 1971, Frances Fox Piven e Richard Cloward publicaram um livro audacioso, tornado a partir de então um clássico, intitulado Regulating the Poor ${ }^{28}$ Mostram aí que as políticas sociais, e nomeadamente a assistência aos pobres, evoluem de maneira cíclica, por contracção e expansão, de maneira a levar os desprovidos ao mercado de trabalho em período económico favorável e a impedir que eles se revoltem em período de vazio. A minha tese é que, trinta anos mais tarde, esta "regulação dos pobres” já não passa apenas pelo welfare, mas implica uma cadeia

26 Loïc Wacquant, Parias urbains. Ghetto, banlieues, État (Paris, La Découverte, 2006).

27 Loïc Wacquant, 1996, "Les banlieues populaires à l'heure de la marginalité avancée", Sciences humaines, 4 (Outono), pp. 30-33.

28 Frances Fox Piven \& Richard Cloward, Regulating the Poor: The Functions of Public Welfare (Nova Iorque, Pantheon Books, 197 i; edição aumentada 1994). 
institucional que liga entre eles os sectores assistencial e penintenciário do Estado. O que implica que, se queremos compreender as políticas de gestão das populações com problemas na base da estrutura das classes e dos lugares, é necessário estudar em conjunto aquilo a que Bourdieu chama a "mão esquerda" e a "mão direita" do Estado. A política social e a política penal convergem e fundem-se: a mesma filosofia beaviorista, as mesmas noções de responsabilidade individual e de contrato, os mesmos dispositivos de vigilância e de registo, as mesmas técnicas de supervisão, rituais de degradação (no sentido de Garfinkel ${ }^{29}$ e sanções dos desvios de comportamento informam a acção dos serviços sociais, transformados em trampolim para o emprego precário, e da polícia, da justiça e da prisão, a quem se pede para conter as populações marginalizadas.

Segue-se então o terceiro volume, que é aquele que escrevi em primeiro lugar por razões de urgência política, Les Prisons de la misère, que demonstra as causas e desmonta os mecanismos de internacionalização da penalização da marginalidade urbana, com a difusão da estratégia policial da "tolerância zero" à escala planetária, concomitante da difusão de políticas económicas neoliberais. ${ }^{30}$ Acrescenta-se um quarto volume, Deadly Symbiosis, que mostra como a divisão etno-racial lubrifica a expansão do Estado penal e acelera a transição da gestão social para a gestão punitiva da pobreza, e como, por sua vez, pela sua acção material e simbólica, a instituição carceral redefine e redinamiza o estigma étnico e etno-nacional. ${ }^{31}$ Este livro mistura etnografia, história social, teoria sociológica e filosofia jurídica, e testa o modelo da fusão estrutural e funcional dos bairros de relegação e do sistema carceral, construído sobre o caso dos Estados Unidos, transportando-o para a Europa para explicar o sobre-emprisionamento dos imigrados pós-coloniais, e no Brasil para aí dar conta da "militarização" das clivagens urbanas na cidade dual.

SD Existe, portanto, não somente um fio condutor existencial, mas também uma costura teórica que liga entre si estas temáticas muito diferentes.

29 Harold Garfinkel, 1956, "Conditions of successful degradation ceremonies", American Journal of Sociology, 61 (Setembro), pp. 240-244.

30 Loïc Wacquant, 2001, "The penalisation of poverty and the rise of neoliberalism", European Journal on Criminal Policy and Research, 9-4 (Inverno), pp. 401-412; trad. portuguesa: "A penalização da miséria e o avanço do neoliberalismo", em Além da Fábrica: Trabalhadores, Sindicatos e a Nova Questão Social, eds. Marco Santana e José Ricardo Ramalho (São Paulo, Boitempo Editorial, 2003), pp. 72-88; Loïc Wacquant, 2003, “Towards a dictatorship over the poor? Notes on the penalization of poverty in Brazil", Punishment \& Society, 5-2 (Abril), pp. 197-205. 31 Loïc Wacquant, 2005, "Race as civic felony", International Social Science Journal, 181 (Primavera), pp. 127-142; trad. portuguesa: "A raça como crime cívico", Sociologia. Revista do Departamento de Sociologia da Faculdade de Letras da Universidade do Porto (Porto), 15, Inverno 2005, pp. 9-41; e Deadly Symbiosis: Race and the Rise of the Penal State (Cambridge, Polity Press, 2009). 
LW São objectos empíricos que são aparentemente muito dispersos e tradicionalmente tratados por sectores distintos da investigação que não comunicam entre si: a antropologia do corpo, a sociologia da pobreza e da dominação racial, e a criminologia. As pessoas que trabalham sobre o corpo, a cultura quotidiana, a produção do desejo não se interessam geralmente pelo Estado; aqueles que decifram as políticas de justiça, tipicamente, não se preocupam nunca com a marginalidade urbana ou com a política social; os especialistas em questões penais não prestam atenção nem ao corpo nem às políticas de Estado que não envolvem oficialmente à luta contra o crime. $\mathrm{O}$ meu argumento é que não podemos separar o corpo, o Estado social ou penal e a marginalidade urbana: é necessário captá-los e explicá-los em conjunto, nas suas imbricações mútuas. A rampa de lançamento teórico desta ogiva analítica de três cabeças é Invitation to Reflexive Sociology, que contém todos os conceitos-chave e os princípios metodológicos accionados nos outros livros.

\section{A ETNOGRAFIA COMO INSTRUMENTO DE RUPTURA E DE CONSTRUÇÃO}

SD O lugar central da etnografia no seu percurso intelectual é claro, mas gostaria que precisasse o papel que ela desempenhou nas diferentes pesquisas que realizou, já que, nos cursos de sociologia, habitualmente não se associa o nome de Bourdieu à etnografia.

LW E erradamente, porque, como já mostrei no artigo que abre o número especial de Ethnography sobre "Pierre Bourdieu in the field", Bourdieu era um dos praticantes mais originais desta abordagem, que além disso foi decisiva na gestão do seu projecto científico. ${ }^{32}$ Ele não escreveu apenas textos que são jóias da arte etnográfica, como "Le sens de l'honneur" (1965) e "La maison Kabyle ou le monde renversé” (1971). A observação de terreno desempenha um papel-chave em todos os seus livros maiores, de Les Héritiers a Les Règles de l'art, passando por La Distinction. ${ }^{33}$

Para não falarmos senão do seu trabalho de juventude, Bourdieu legou-nos uma extraordinária etnografia comparada, levada a cabo dos dois lados do Mediterrâneo, das transformações cataclísmicas das estruturas sociais e mentais das sociedades camponesas, na Cabília, sob o efeito da penetração colonial francesa e da guerra de libertação nacional, e na sua aldeia do Béarn,

32 Loïc Wacquant, 2004, "Following Pierre Bourdieu into the field," Ethnography, 5-4 (Dezembro), pp. 387-414; traduções portuguesas: 2004, "Seguindo Pierre Bourdieu no terreno", Cadernos de Ciências Sociais (Lisboa), número especial "Génese e legado da obra de Pierre Bourdieu", 24 (Abril), pp. 69-96; 2006, "Seguindo Pierre Bourdieu no campo", Revista de Sociologia e Política, número especial "Bourdieu no campo", 26-2 (Junho), pp. 13-29.

33 Pierre Bourdieu, "Sens de l'honneur" e "Maison Kabyle”, em Esquisse d'une théorie de la pratique. Précédée de trois études d'ethnologie Kabyle (Genebra, Editions Droz, 1972 ; reed. Paris, Seuil/Points, 2000). 
sob o efeito da generalização da escolarização, da abertura do espaço aldeão (villageois) às trocas comerciais e da influência da cultura urbana por intermédio dos media. ${ }^{34}$ Os que insistem em fazer dele um "teórico da reprodução" fariam bem em reler estes estudos... Bourdieu fazia etnografia comparada, em vários locais (sites) em simultâneo e combinada com análise estatística, trinta anos antes de surgir a moda da etnografia multi-site - que frequentemente não consegue esconder uma prática que se assemelha mais ao turismo cultural do que a um trabalho de terreno digno desse nome. E uma etnografia que, longe de ceder ao exotismo e ao empirismo, era solidamente orientada por um projecto teórico que acabava retroactivamente por alimentar: a maior parte dos conceitos-chave de Bourdieu, como o de habitus, têm a sua origem num puzzle encontrado no terreno. Além disso, sempre houve na senda de Bourdieu, no Centro de Sociologia Europeia e noutros locais, praticantes da etnografia de primeira água: penso nomeadamente em Abdelmalek Sayad, em Stéphane Beaud e Michel Pialoux, em Yvette Delsaut ou ainda em Monique e Michel Pinçon. ${ }^{35}$

O que quer dizer que eu não teria tido falta de modelos a imitar se tivesse querido ser etnógrafo por uma espécie de decisão deliberada. Mas a questão de ir ou não para o terreno nunca se me pôs em termos de vocação metodológica. Foi mais o método que se me impôs como o mais adequado para resolver o problema concreto com que me confrontava, que, em Chicago, não era apenas o de me "aproximar" do gueto para dele adquirir um conhecimento prático e vivenciado por dentro, mas também o de me dotar de um instrumento de desconstrução das categorias através das quais a "cintura negra" americana era então percepcionada e pensada no debate universitário e político. A minha intenção inicial era a de me apoiar sobre uma etnografia do cenário urbano do South Side para ultrapassar o duplo ecrã constituído pelo discurso pré-fabricado sobre o gueto como local de desorganização social - espaço de violência, de desviância, de vazio, caracterizado pela ausência e a carência - decorrente do ponto de vista externo e exotisante que a sociologia estabelecida adopta, e pela fábula académica de underclass, essa categoria-espantalho que apareceu nos anos 1980-90 no imaginário social e científico dos Estados Unidos para explicar de maneira perfeitamente tautológica o descalabro do gueto negro pelo

34 Pierre Bourdieu (com A. Darbel, J.-P. Rivet e C. Seibel), Travail et travailleurs en Algérie (Paris-La Haye, Mouton, 1963); Pierre Bourdieu e Abdelmalek Sayad, Le Déracinement. La Crise de l'agriculture traditionnelle en Algérie (Paris, Éd. de Minuit, 1964); Pierre Bourdieu, Le Bal des célibataires. Crise de la societé paysanne en Béarn (Paris, Seuil, 2002, 1. ${ }^{a}$ ed. 1962).

35 Abdelmalek Sayad, Un Nanterre Algérien, terre de bidonvilles (Paris, Editions Autrement, 1995); Stéphane Beaud e Michel Pialoux, Retour sur la condition ouvrière. Enquête aux usines Peugeot de Sochaux-Montbéliard (Paris, Fayard, 1999); Yvette Delsaut, La Place du maître. Une chronique des Écoles Normales d'Instituteurs (Paris, L'Harmattan, 1992); Michel Pinçon e Monique Pinçon-Charlot, Voyage en grande bourgeoisie. Journal d'enquête (Paris, Presses Universitaires de France, 1997). 
“comportamento antisocial" dos seus membros. ${ }^{36}$ A observação etnográfica permitiu-me efectuar uma dupla ruptura, com a representação mediático-política dominante e com o senso comum erudito da época, ele próprio fortemente contaminado pela doxa nacional. O mesmo se verificou do lado francês, onde o confronto entre o que vi e ouvi nos serviços do Ministério das Cidades e na Cité des Quatre Mille em La Courneuve me permitiu passar pelo crivo os preconceitos burocráticos e semieruditos que obstaculizam a construção do objecto "banlieues".

SD Essa intenção é explicitada no prólogo metodológico de Parias urbains, onde menciona o contributo da etnografia entre cinco princípios para orientar a sociologia comparada da marginalidade urbana.

LW Parias urbains não é uma monografia de terreno no sentido clássico, dado que a análise articula os níveis "micro" do bairro, "meso" da cidade e do quadro político local e "macro" da economia e do Estado nacional, e combina observação directa, dados estatísticos e perspectivação histórica e comparativa. ${ }^{37}$ Mas a etnografia não deixa de desempenhar também uma função relevante em dois registos analíticos: como instrumento de ruptura com a doxa política e intelectual, como acabo de referir, e como utensílio de construção teórica.

As observações registadas dia a dia no gueto negro de Chicago na senda dos meus colegas da sala de boxe sobre as suas relações com os empregadores, as instituições de apoio social, a polícia, os gangues, a escola, etc. permitiram-me elaborar as noções ideal-típicas que utilizo para descodificar as práticas sociais e a experiência vivida da pobreza no coração segregado da metrópole estadunidense. Assim, a noção de hipergueto exprime o esmagamento do espaço dos possíveis e o clima de enclausuramento social e racial que impregnam o South Side nos anos de 1990, de que não se pode fazer ideia se não se puserem lá os pés. O esquema da marginalidade avançada, desenvolvida na terceira parte do livro e que caracteriza o novo regime de pobreza que emerge na era post-keynesiana e post-fordista, apoia-se no conhecimento directo das estratégias de vida dos habitantes do gueto negro americano e nos subúrbios franceses em declínio, formas vivas da consciência colectiva que orientam as suas acções e

36 Loïc Wacquant, 1997, "Three pernicious premises in the study of the American ghetto," International Journal of Urban and Regional Research, 21-2 (Junho), "Events and debate", pp. 341-353 (e as 8 respostas nos números seguintes); trad. portuguesa abreviada: "Três premissas perniciosas no estudo do gueto norte-americano", Mana: Estudos de Antropologia Social (Rio de Janeiro), 2-2, Outubro 1996, pp. 145-161. Loïc Wacquant, "L"underclass' urbaine dans l'imaginaire social et scientifique américain", em L'Exclusion: l'état des savoirs (Paris, Editions La Découverte, 1996, pp. 248-262); trad. portuguesa: "A 'underclass' urbana no imaginário social e científico norte-americano”, Estudos Afro-Asiáticos, 31 (Rio de Janeiro), Outubro, 1997, pp. 37-50.

37 Loïc Wacquant, Parias urbains. Ghetto, banlieues, État (Paris, La Découverte, 2006). 
obstáculos concretos com que embarram - como a ausência de uma linguagem comum, que reforça no plano simbólico a dispersão objectiva do "precariado". O conceito de estigmatização territorial, como modalidade distintiva do descrédito colectivo lançado sobre os residentes dos bairros de relegação na era do salariado dessocializado, encontra a sua origem no inquérito levado a cabo face a face junto dos responsáveis pela política da cidade em França. ${ }^{38}$ Os altos funcionários que eu inquiria falavam todos dos bairros populares da periferia com trémulos de angústia e de repulsa na voz; tudo no seu tom, no seu vocabulário, na sua postura e nos seus gestos exprimia o desprazer de estar encarregado de uma missão e de uma população aviltada e portanto aviltante. Depois encontrei o mesmo sentimento de repulsa e de indignidade no nível mais baixo da escala urbana, tanto entre os habitantes da Cité des Quatre Mille nos subúrbios de Paris, como nos negros americanos apanhados na armadilha do hipergueto em Chicago. Não teria podido desenvolver esta noção - que me surge retrospectivamente como um dos resultados mais convincentes desta pesquisa - sem o trabalho de terreno levado a cabo em paralelo dos dois lados do Atlântico.

SD Como é que a estigmatização territorial se distingue da estigmatização étnica e em que é que ela é, quanto a si, tão importante?

LW Os bairros operários, deserdados ou imigrados nunca tiveram boa reputação, a cidade sempre teve os seus bas-fonds e os seus sectores suspeitos cercados por uma aura sulfurosa. Mas um fenómeno novo apareceu no decurso dos dois últimos decénios: em todos os países avançados um pequeno número de bairros ou de localidades são a partir de então publicamente conhecidos como poços de perdição social e moral. O grande aglomerado (ensemble) de Robert Taylor Homes em Chicago, Bobigny na periferia de Paris, o distrito de Moss Side em Manchester, Tensta às portas de Estocolmo, São João de Deus no nordeste do Porto: estes nomes são outros tantos hipónimos nacionais do "horror urbano"; eles inspiram medo e desprezo em toda a sociedade. Cristalizou-se um aviltamento do local, que se acrescenta à desonra de classe e de etnicidade que atinge os seus habitantes, com efeitos próprios, distintos das "marcas" tribais, morais ou corporais outrora estudadas por Erving Goffman, ${ }^{39}$ as quais contribuem poderosamente para a espiral da desintegração social e da difamação simbólica.

38 Loïc Wacquant, 2007, "Territorial stigmatization in the age of advanced marginality", Thesis Eleven, 91 (Novembro), pp. 66-77; trad. portuguesa: "A estigmatização territorial na idade da marginalidade avançada," Sociologia. Revista do Departamento de Sociologia da Faculdade de Letras da Universidade do Porto (Porto), 16 (Outono 2006), pp. 27-39.

39 Erving Goffman, Stigma: Notes on the Management of Spoiled Identity (Nova Iorque, Simon \& Schuster, 1963). 
Quando perguntava aos habitantes do gueto de Chicago e da cidade de La Courneuve, duas zonas de relegação a seis mil quilómetros de distância, "o que fazem as pessoas do bairro para se desenvencilharem no dia-a-dia?", eles respondiam de imediato em termos quase idênticos: "Ah, eu não conheço as pessoas do bairro. Vivo aqui mas não sou daqui" - ou seja, eu não sou como "eles". Demarcavam-se dos vizinhos e lançavam sobre estes a imagem degradada que deles dá o discurso público. Dos dois lados do Atlântico, os habitantes das zonas percepcionadas e vividas como purgatórios urbanos escondem a morada aos empregadores, aos serviços públicos, evitam receber amigos em casa e negam pertencer à micro-sociedade local. Só a pesquisa no terreno podia revelar o grau de impregnação deste sentimento de indignidade nos dois lugares e o recurso às mesmas estratégias de gestão do estigma territorial que são a distanciação mútua e a depreciação lateral, a retirada para a esfera privada e a fuga para o exterior logo que se conseguem meios para tal. Estas estratégias tendem a desagregar um pouco mais os colectivos já enfraquecidos das zonas

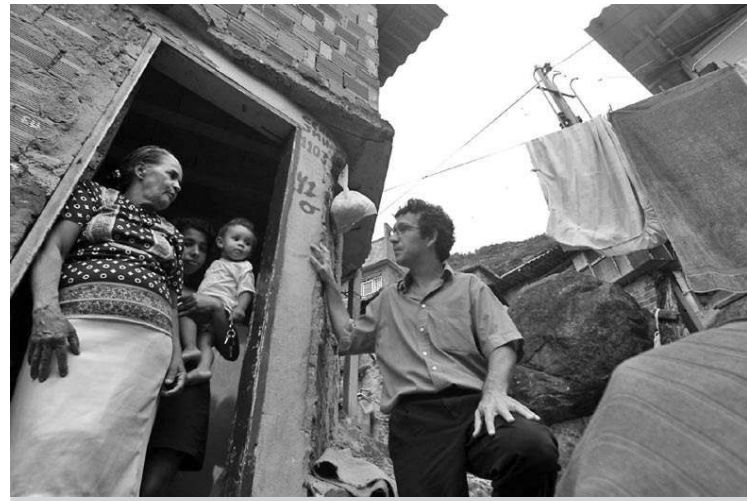

Na favela de Santa Marta, Rio de Janeiro (2001). urbanas deserdadas e a produzir a "desorganização" que o discurso dominante precisamente diz caracterizar essas zonas. $\mathrm{O}$ estigma territorial incita igualmente o Estado a adoptar políticas específicas, derrogatórias do direito comum e da norma nacional, que na maior parte das vezes reforçam a dinâmica de marginalização que pretendem combater, em detrimento dos habitantes.

\section{A CARNE E O TEXTO}

SD Do ponto de vista do método, da escala e do objecto, a etnografia do ofício de boxeur em Woodlawn é muito diferente. Como é que ela se desenvolveu?

LW É uma etnografia de feição clássica pelos seus parâmetros, uma espécie de estudo de uma colectividade local tal como era feito pela antropologia britânica nos anos 1940, com a diferença que a minha aldeia é a sala de boxe e as suas extensões, e a minha tribo os boxeurs e o seu círculo. ${ }^{40}$ Retive esta

40 Loïc Wacquant, Corps et âme. Carnets ethnographiques d'un apprenti boxeur (Marselha e Montreal, Agone, Comeau \& Nadeau, 2000); trad. portuguesa: Corpo e Alma. Notas Etnográficas de um Apprendiz de Boxe (Rio de Janeiro, Relume Dumará, 2002). 
unidade estrutural e funcional porque ela abarca os boxeurs e delimita um horizonte temporal, relacional, mental, emocional e estético específico, que separa o pugilista e o faz elevar-se acima do seu meio habitual. Quis, antes de mais, dissecar a relação bífida de "oposição simbiótica" entre o gueto e o ginásio, a rua e o ringue; em seguida, mostrar como a estrutura social e simbólica da sala governa a transmissão da técnica da "nobre" arte e a produção da crença colectiva na illusio pugilística; finalmente, penetrar a lógica prática de uma prática corporal no limite da prática através de uma aprendizagem de longa duração na primeira pessoa. Durante três anos fundi-me na paisagem local e entrei no jogo. Aprendi a jogar boxe e participei em todas as fases da preparação do boxeur, até combater por altura do grande torneio dos Golden Gloves. Segui os meus companheiros de sala nas suas peregrinações pessoais e profissionais. E lidei no dia-a-dia com treinadores, agentes, promotores, etc., que fazem girar o planeta do soco (cogne). Actuando assim, fui aspirado pela espiral sensual e moral do pugilismo, ao ponto de encarar a hipótese de interromper a minha trajectória universitária para me tornar profissional.

O que quer dizer que o objecto e o método desta pesquisa, esses, não são clássicos. Corps et âme apresenta uma radicalização empírica e metodológica da teoria do habitus de Bourdieu. ${ }^{41}$ Por um lado, abro a "caixa negra" do habitus pugilístico, escalpelizando a produção e a junção das categorias cognitivas, das destrezas corporais e dos desejos que, combinados, definem a competência e a apetência próprias do jogador de boxe. Por outro, desenvolvo o habitus como dispositivo metodológico, quer dizer que me coloco na situação de adquirir, pela prática, em tempo real, as disposições do pugilista, a fim de elucidar o magnetismo próprio ao cosmos pugilístico. O método põe, pois, à prova a teoria da acção que anima a análise segundo um dispositivo de pesquisa recursivo e reflexivo.

A ideia que me orientava aqui era a de levar a lógica da observação participante até inverter esta dualidade e fazer participação observante. Na tradição anglo-americana, diz-se aos estudantes de antropologia, quando eles se iniciam no trabalho de terreno: "Don’t go native". Na tradição francesa, pode admitir-se a imersão radical - veja-se Jeanne Favret-Saada em Les Mots, la mort, les sorts ${ }^{42}$ - mas com a condição de ela ser acompanhada por uma epistemologia subjectivista que nos remete para o interior do antropólogo-sujeito. Eu, pelo contrário, digo "go native", mas "go native armed", ou seja, equipado com todos os instrumentos teóricos e metodológicos, com todas as problemáticas herdadas da vossa

41 Loïc Wacquant, 2002, “Taking Bourdieu into the field”, Berkeley Journal of Sociology, 46, pp. 180-186; tradução portuguesa: 2002,"Levando Bourdieu ao campo," Revista de Sociologia e Política, 19 (Novembro), pp. 100-104; "Habitus”, em Jens Beckert e Milan Zafirovski (dirs.), International Encyclopedia of Economic Sociology (Londres, Routledge, 2004), pp. 315-319; tradução portuguesa: 2004, "Esclarecer o habitus", Sociologia. Revista do Departamento de Sociologia da Faculdade de Letras da Universidade do Porto (Porto), 14 (Outono), pp. 35-40.

42 Jeanne Favret-Saada, Les Mots, la mort, les sorts (Paris, Gallimard/Poche, 1985). 
disciplina, com a vossa capacidade de reflexão e de análise, e guiado por um esforço constante para, depois de ter passado pela prova iniciática, objectivar essa experiência e construir o objecto - de preferência a deixar-se ingenuamente envolver e construir por ele. Vá, torne-se um indígena, mas volte como soció$\log$ !

SD É esta iniciação guiada pela teoria que faz a originalidade de Corps et âme, a avaliar pelas numerosas reacções que o livro suscitou (traduzido em nove línguas e muito amplamente recenseado fora da sociologia).

LW Sobre as reacções, não tenho certezas! Creio, com grande pena minha, uma vez que a intenção principal da investigação é desexoticizar o ofício do soco, que o impacto do livro se deve em parte ao lado "sensacional" do trabalho de terreno: deixar que nos partam o nariz para compreender o que é tornar-se pugilista não é comum, ainda menos se se trata de um francesinho branco que se intromete no assunto no gueto negro americano. Alguns dos meus críticos, tomando erradamente o meu trabalho por uma extensão dos "estudos de profissão" à maneira da segunda Escola de Chicago, nem sequer se aperceberam do duplo papel que o conceito de habitus desempenha na investigação e lamentaram-se da ausência de teoria no livro. ${ }^{43}$

De facto, a teoria e o método estão articuladas ao ponto de se fundirem no próprio objecto empírico que permitem elaborar. Corps et âme é uma etnografia experimental no sentido original do termo, uma vez que o investigador é um dos corpos socializados lançados no alambique sociomoral e sensual da sala de boxe, corpo em acção cuja transmutação se vai efectuar para apreender a alquimia através da qual se fabrica o boxeur. A aprendizagem é aqui o meio de se adquirir um domínio prático (maîtrise pratique), um conhecimento visceral do universo em questão, de penetrar a praxiologia dos agentes em questão e não de entrar na subjectividade do investigador. Não é de modo algum uma queda no poço sem fundo do subjectivismo, no qual se lança a "auto-etnografia", pelo contrário: é um apoiar-se sobre a experiência mais íntima, a do corpo desejante que sofre, para captar in vivo a fabricação colectiva dos esquemas de percepção, de apreciação e de acção pugilísticas que são partilhadas, muito ou pouco, por todos os boxeurs, seja qual for a sua origem, a sua trajectória, o seu nível na hierarquia desportiva. ${ }^{44}$ A personagem central da história não é nem Busy Louie, nem este ou aquele boxeur, nem mesmo DeeDee, o velho treinador, a despeito da sua posição de chefe de orquestra: é o ginásio enquanto forja social

43 Loïc Wacquant, 2005, "Shadowboxing with ethnographic ghosts: A rejoinder", Symbolic Interaction, 28-3 (Verão), pp. 441-447 (resposta ao simpósio sobre Body and Soul).

44 Loïc Wacquant, 2005, "Carnal connections: On embodiment, membership, and apprenticeship", Qualitative Sociology, 28-4 (Inverno), pp. 445-47 I (resposta ao número especial consagrado a Body and Soul, 28-3, Outono de 2005). 
e moral. O modelo intelectual não é Castañeda e os seus feiticeiros Yaqui, mas o Bachelard do Racionalismo aplicado e da poética materialista do espaço, do tempo e do fogo. ${ }^{45}$

De facto, penso que fiz, de maneira explícita, metódica e principalmente extrema, o que faz qualquer bom etnógrafo: conseguir uma apreensão prática, táctil, sensorial da realidade prosaica que estuda, de modo a elucidar as categorias e as relações que organizam o comportamento e os sentimentos comuns das pessoas que estuda. Com a diferença que habitualmente isso é feito sem ser dito, ou sem se tematizar o papel da "co-presença" no fenómeno ou fazendo(-se) acreditar que é um processo mental e não uma aprendizagem corporal e sensual que é prévia à consciência até passar pela mediação da linguagem. Corps et âme traz a demonstração em actos das possibilidades e das virtudes distintivas de uma sociologia carnal, ${ }^{46}$ que tem plenamente em conta o facto de o agente social ser um animal que sofre, um ser de carne e sangue, de nervos e vísceras, habitado por paixões e dotado de saberes e de habilidades incorporadas - por oposição ao animal symbolicum da tradição neo-kantiana, retomada por Clifford Geertz e pelos defensores da antropologia interpretativa, por um

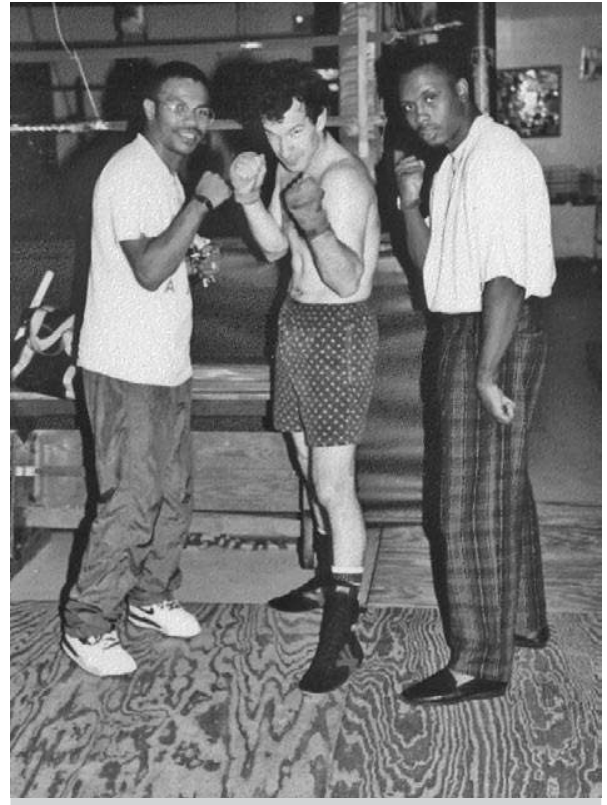

Curtis, "Busy" Louie e Tony em pose no Woodlawn Boys Club em South Side, Chicago, 1990. lado, e por Herbert Blumer e o interaccionismo simbólico, por outro ${ }^{47}$ e que isso é também verdade para o sociólogo. Isso implica pôr o corpo do sociólogo em jogo e tratar o seu organismo inteligente não como um obstáculo ao saber, como queria o intelectualismo enfeudado à concepção indígena da prática intelectual, mas como vector de conhecimento do mundo social.

45 Gaston Bachelard, Le Rationalisme appliqué (Paris, PUF, 1949); La Psychanalyse du feu (Paris, Gallimard, 1938); La Poétique de l'espace (Paris, PUF, 1957).

46 Loïc Wacquant, 2003, "Une expérience de sociologie charnelle”, Solidarités, 29 (Junho), pp. 18-20; trad. portuguesa: 2005, "Como se faz um boxeur: uma experiência de sociologia carnal”, Fórum Sociológico (Lisboa), 13-14, segunda série, pp. 191-198.

47 Clifford Geertz, The Interpretation of Cultures (Nova Iorque, Basic Books, 1974); Herbert Blumer, Symbolic Interaction (Englewood Cliffs, Prentice-Hall, 1966). 
SD Mas então, se Corps et âme não se centra sobre a pessoa de Busy Louie, o sociólogo-boxeur em aprendizagem, isso quer dizer que não é um livro de antropologia reflexiva?

LW Não no sentido em que a entende a antropologia dita "pós-estruturalista" ou "pós-moderna", para a qual a atenção do olhar analítico é dirigida quer sobre o sujeito de conhecimento na sua intimidade pessoal, quer sobre o texto que dirige aos pares e os circuitos de poder-saber nos quais ele circula. Estas formas de reflexividade nascísica e discursiva são muito superficiais; elas podem ser sem dúvida um momento útil na pesquisa para limitar os enviesamentos mais grosseiros (identidade e trajectórias sociais, afectos, efeitos retóricos, etc.). Mas elas param o movimento de autocrítica precisamente aí onde ele deveria começar, a saber, o questionamento contínuo das categorias e das técnicas de análise sociológica e da relação com o mundo que elas pressupõem. É este retorno aos instrumentos de construção do objecto, por oposição ao sujeito da objectivação, que é a marca distintiva do que se pode chamar a reflexividade epistémica..$^{48}$ Outra diferença relativamente à reflexividade "égologique" ou textual dos antropólogos subjectivistas: ela manifesta-se não no fim do projecto, ex post, no momento de se redigir o relatório, mas durante, em todas as etapas da investigação. Ela visa o conjunto das operações mais rotineiras, desde a selecção do local de observação e dos informadores até às questões a pôr ou a evitar, passando pelo envolvimento dos esquemas teóricos, dos utensílios metodológicos e das técnicas de exposição, no momento em que são efectuadas.

Corps et âme é pois um livro reflexivo, no sentido em que o próprio dispositivo da investigação me forçava permanentemente a reflectir sobre a adequação dos meios de investigação ao seu fim, sobre a diferença entre domínio prático (maîtrise pratique) e domínio teórico (maîtrise théorique) de uma prática, sobre a margem entre o entusiasmo sensorial e a compreensão analítica, o visceral e o mental, o ethos e o logos, do pugilismo mas também da sociologia. De igual modo, Parias urbains é uma obra de sociologia urbana reflexiva, porque questiona sem cessar as próprias categorias que põe em causa e em jogo - underclass, inner city, banlieues, hipergueto, relegação, precariado - para pensar as novas configurações da marginalidade na cidade. E porque se apoia sobre uma demarcação clara entre categorias indígenas e categorias analíticas, que é para mim a base da reflexividade.

A reflexividade epistémica impõe-se ao etnógrafo com uma urgência tanto maior quanto tudo o convida a submeter-se às pré-construções do senso comum. Por

48 Pierre Bourdieu e Loïc Wacquant, An Invitation to Reflexive Sociology (Chicago, University of Chicago Press, 1992), pp. 36-46; Pierre Bourdieu, 2002, "Participant objectivation: The Huxley medal lecture”, Journal of the Royal Anthropological Institute, 9-2 (Fevereiro), pp. 281-294. 
dever metodológico, tem a obrigação de ouvir os agentes que estuda e levar a sério o seu "ponto de vista". Se fizer bem o seu trabalho, encontrar-se-á ligado a eles por laços afectivos que encorajam a identificação e o transfert. Enfim, a imagem pública da etnografia (incluindo junto de outros investigadores em ciências sociais, infelizmente) aproxima-a da narrativa, do jornal íntimo, e mesmo da epopeia. É por isso que o antropólogo ou o sociólogo que recorre ao trabalho de terreno deve redobrar de reflexividade. Foi o que tentei mostrar em "Scrutinizing the street", a propósito de derivas recentes na etnografia urbana norte-americana. ${ }^{49} \mathrm{O}$ verdadeiro objecto da minha crítica não são os três livros que submeto ao crivo analítico (e ainda menos os seus autores, que não são aqui senão pontos no espaço académico), ou as suas opções políticas, que me são indiferentes, mas uma certa postura epistemológica de abandono às formas de percepção indígenas, ao moralismo vulgar, às seduções do pensamento oficial e às regras da etiqueta académica. Esta postura está na base de erros científicos graves, porque formam sistema e têm em seu favor o senso comum corrente e o senso comum erudito.

SD Corps et âme inova também na forma, pela sua escrita narrativa de estilo quase-teatral, que convida o leitor a vibrar com o boxeur-aprendiz e que dá a ver simultaneamente a lógica do trabalho de terreno e o seu produto.

LW Como passar das entranhas ao intelecto, da compreensão do corpo ao saber do texto? Eis um verdadeiro problema de epistemologia concreta sobre o qual não se reflectiu o suficiente e que durante muito tempo me pareceu insolúvel. Restituir a dimensão carnal da existência vulgar e a ancoragem corporal do saber prático constitutivo do pugilismo - como ainda de quaisquer práticas, mesmo das aparentemente menos "corpóreas" (corporées) - requer com efeito uma revisão profunda do nosso modo de redigir a ciência social. No caso presente, era-me necessário encontrar um estilo em ruptura com a escrita monológica, monocromática, linear do relato clássico do qual o etnógrafo se retirou, e conseguir afinar uma escrita com várias facetas, misturando os estilos e os géneros, a fim de captar e transmitir ao leitor "a dor e o sabor da acção". ${ }^{50}$

Corps et âme foi escrito contra o subjectivismo, contra o narcisismo e o irracionalismo que subjazem a uma certa teoria literária dita "pós-moderna", mas isso não quer dizer que por isso nos devamos privar das técnicas literárias e dos instrumentos de exposição dramática que essa tradição nos dá. É por isso

49 Loïc Wacquant, 2002, "Scrutinizing the street: Poverty, morality, and the pitfalls of urban ethnography”, American Journal of Sociology, 107-6 (Maio), pp. 1468-1532.

50 Loïc Wacquant, 2002, "O sabor e a dor da ação", prefácio de Corpo e Alma. Notas Etnográficas de um Aprendiz de Boxe (Rio de Janeiro, Relume Dumará, 2002), pp. 11-17. 
que o livro mistura três formas de escrita que, entrecruzando-se ao longo das páginas, partilham a prioridade nas três partes, de tal modo que o leitor passa insensivelmente do conceito ao percebido (percept), da análise à experiência. A primeira parte adopta uma escrita sociológica clássica de tipo analítico, que isola de imediato as estruturas e os mecanismos de modo a dar ao leitor os instrumentos necessários para explicar e compreender o que se passa. O tom da segunda parte é dado por uma escrita etnográfica stricto sensu, quer dizer, reveladora das maneiras de ser, de pensar, de sentir e de agir próprias do meio considerado, onde se encontram aqueles mesmos mecanismos mas em acção, através dos seus produtos. Com a terceira parte vem o momento experiencial, sob a forma de uma "novela sociológica" que revela a experiência vivida do sujeito, que, no caso, é também o analista.

A combinação reflectida destas três modalidades de escrita - sociológica, etnográfica e literária -, segundo proporções que se vão invertendo ao longo das páginas, visa simultaneamente permitir ao leitor sentir emocionalmente e compreender racionalmente as possibilidades e manobras da acção pugilística. Para isso o texto constrói uma trama analítica, páginas de notas de terreno cuidadosamente editadas, contrapontos feitos de retratos de personagens-chave e de extractos de entrevistas, e fotografias cuja função é facilitar uma apropriação sintética do jogo dinâmico dos factores e das formas inventariadas na análise, de dar a "tocar com os olhos" o pulso palpitante do pugilismo. Aí ainda, a teoria do habitus, o recurso à aprendizagem como técnica de investigação, o lugar atribuído ao corpo fazem o seu caminho como vector de conhecimento e de inovação formal na escrita: tudo se encaixa. Não serve de nada fazer uma sociologia carnal apoiada numa iniciação prática se o que ela revela do magnetismo sensoriomotor do universo em questão desaparece com a redacção, a pretexto de que se devem respeitar cânones textuais ditados pelo positivismo ou pelo cognitivismo neo-kantiano.

\section{DE TRENÓ ATRAVÉS DO ATLÂNTICO}

SD Voltemos à sua posição de sociólogo europeu que trabalha nos Estados Unidos, uma ocasião para reflectir na concepção do intelectual vigente nos dois lados do Atlântico.

LW Eu estou na charneira - ou colocado em falso - entre duas tradições, duas concepções do trabalho de pesquisa. Existe, de um lado, uma tradição europeia, incarnada pela França, que inventou a categoria sócio-histórica do intelectual na altura do caso Dreyfus, como bem mostrou Christophe Charle no seu magnífico livro Naissance des "intellectuels". Para esta linhagem, que, grosso modo, vai de Zola a Sartre, e depois de Foucault a Bourdieu e outros, o intelectual é um produtor cultural que por definição compromete a sua 
competência específica no debate público. ${ }^{51}$ Necessariamente implicado na Cidade, é seu dever reinjectar na esfera cívica e política o fruto das suas reflexões e das suas observações. Eu sou um produto desta tradição. Mas acontece que eu desenvolvo os meus trabalhos principalmente do outro lado do Atlântico, onde reina uma outra tradição, mais ciosa de rigor metodológico, para a qual o investigador é incarnado não pelo intelectual (uma palavra pejorativa nos Estados Unidos), mas pelo professional, no sentido do advogado ou do médico, ou seja, o detentor de uma competência técnica e de um saber pericial que é um saber neutro, que só deve ser julgado pelos seus pares e que por isso deve manter-se à margem do debate público. O intelectual é bidimensional, simultaneamente sábio e cidadão activo; o académico é unidimensional, exclusivamente virado para o microcosmo universitário - sob pena de se ver desacreditado. Esta é para mim uma tensão profissional e existencial que nem sempre é fácil de gerir.

Claro que cada uma destas tradições tem os seus prós e os seus contras. Mais do que fecharmo-nos na celebração ritual de uma concepção da vocação de investigador e na depreciação da outra, devemos esforçar-nos por tornar cumulativas as suas qualidades distintivas. A força do padrão americano reside no rigor metodológico que ele prescreve e que trava, quando não interdita, o amadorismo. A perversão do padrão francês, pelo contrário, reside na grande tolerância que atribui ao diletantismo intelectual e ao ensaísmo de pretensão filosófica - incarnado até à caricatura pelo que Louis Pinto chama "o intelectual mediático", que só existe através de e para os média. ${ }^{52}$ Quantos dos nossos grandes "filósofos" parisienses, omnipresentes nos magazines culturais e nos estúdios de televisão, nunca publicaram o mais pequeno trabalho numa revista séria de filosofia ou de ciências sociais. Mas enquanto os seus amigos jornalistas se maravilharem com o seu sonoro pensamento, eles existirão enquanto tal... Nos dois lados do Atlântico, os investigadores autónomos são cada vez mais dobrados pelos experts burocráticos, sábios da sombra que dão aos governantes as respostas que desejam e que sobretudo aceitam as suas questões. Com efeito, há em todos os países um défice de reflexão colectiva sobre a organização colectiva do trabalho científico e sobre as relações instáveis entre a investigação, os média, o dinheiro e a política. É este défice que favorece a heteronímia científica e, a partir daí, a difusão do "pensamento único" neoliberal que trunca e paraliza o debate público há um decénio. ${ }^{53}$

51 Christophe Charle, Naissance des "intellectuels" (1880-1900) (Paris, Éditions de Minuit, 1990).

52 Louis Pinto, La Vocation et le métier de philosophe. Pour une sociologie de la philosophie dans la France contemporaine (Paris, Seuil, 2007).

53 Pierre Bourdieu e Loïc Wacquant, 1998, "Les ruses de la raison impérialiste", Actes de la recherche en sciences sociales, 121-122 (Março), pp. 109-118; trad. portuguesa: "Sobre as artimanhas da razão imperialista”, em Escritos de Educação, Petrópolis, Editora Vozes, 1999, pp. 17-32. 
SD O senhor partilha o seu tempo entre os Estados Unidos e a Europa, mas com o que é que, concretamente, se parece a vida quotidiana de Loïc Wacquant?

LW É melhor não a tentar descrever! É frenética... é um pouco como andar de trenó, em que se está estendido junto ao solo num bólido que desce a montanha a uma velocidade vertiginosa. Aí está, a vida quotidiana de Loïc Wacquant é praticar trenó intelectual mas sem gelo [risos]... Uma confidência, só: é raro deitar-me cedo e não vou muitas vezes ao cinema.

A minha vida quotidiana é parecida com a de todos os investigadores. Quando estou nos Estados Unidos, para ensinar e no meu principal terreno, tenho uma vida de eremita, estou bastante enclausurado, isolado no mundo universitário, que é ele próprio totalmente isolado da sociedade envolvente e estruturalmente desconectado da esfera política. Concentro-me, portanto, nas minhas pesquisas, nas minhas aulas, no acompanhamento dos doutorandos, na redacção da Ethnography, etc. É 95\% do meu tempo e da minha energia, e é a base de tudo: sem trabalho científico sério, sem conhecimento avaliado e aprovado, nada teria a dizer. É quando venho à Europa que o lado "intelectual comprometido" (como dizem os meus colegas americanos) sobressai. Uma vez atravessado o Atlântico, dou conferências e participo em colóquios científicos, mas tomo parte de vez em quando em acontecimentos extra-universitários, em debates públicos que são uma ocasião para intervir nos assuntos em que tenho competência. Felizmente que esta possibilidade de sair do bocal universitário existe na Europa e na América Latina, senão creio que estaria completamente ressequido humana e intelectualmente. Quando se permanece fechado no cenáculo universitário, deixamo-nos enredar pelos jogos e paradas (jeux et enjeux) do microcosmos, e no final perdemos a energia cívica, a capacidade de nos espantarmos perante o mundo e a habilidade para o decifrar.

Por vezes tenho a sensação de ter uma existência desdobrada ou desmultiplicada, com momentos de tensão entre os diferentes assuntos que aprofundo, entre o plano científico e o plano político, entre os públicos universitários e os militantes, entre os Estados Unidos e a Europa, onde, como disse, prevalecem concepções diferentes da actividade intelectual e, portanto, imagens bastante diferentes do meu trabalho. Por vezes estas duas dimensões entram em choque e é difícil, mesmo doloroso; mas quando elas entram em sinergia, então tenho a sensação de fazer o meu trabalho em pleno. Um exemplo: em Fevereiro passado, na altura em que a campanha presidencial arrancava em França, participei num debate público sobre os Parias urbains organizado pela Utopia, um grupo de militantes de esquerda "transcorrentes", em que o comentador do livro era o antigo ministro do Interior da esquerda pluralista, Jean-Pierre Chevènement, que eu tinha fustigado no meu livro anterior Les Prisons de la misère. Era uma discussão tão séria como a que tinha tido na semana anterior com colegas britânicos sociólogos e urbanólogos em Cambridge, mas mais aberta e mais 
arriscada. Foi muito estimulante confrontar as nossas perspectivas sobre a marginalização das periferias populares e sobre as soluções que o Estado thes poderia trazer, reflectir em voz alta sobre como prolongar as minhas análises em medidas práticas, sem nada ceder em rigor teórico e empírico. ${ }^{54}$

Em França ou em Portugal, na Argentina, no México ou na Bélgica, quando dou conferências, o público é frequentemente uma amálgama heterogénea de universitários, de militantes políticos, de defensores dos direitos do homem, de pessoas oriundas de meios profissionais diversos, como professores, trabalhadores sociais, cidadãos comuns. Isto dá a possibilidade de se ter um diálogo mais amplo e mais aberto, onde o olhar e a linguagem eruditos são, eles próprios, questionados e onde se coloca o problema de retraduzir em termos cívicos e práticos os resultados dos trabalhos que foram conduzidos num quadro especificamente científico.

\section{SD E isso não é possível nos Estados Unidos?}

LW Este espaço de "tradução" colectiva é extremamente reduzido, dada a inacessibilidade do campo político e o autofechamento das profissões universitárias. Por exemplo, enquanto que na Europa ou na América Latina intervim cem vezes sobre o problema das prisões na rádio, na televisão, nos grandes jornais diários e fui consultado pelos altos responsáveis administrativos ou políticos, nos Estados Unidos não dei uma única conferência sobre as prisões fora do quadro universitário, onde o público-tipo é composto quase exclusivamente por estudantes e professsores, sociólogos, criminalistas ou juristas. E não se trata de um defeito pessoal: é verdade para todos os investigadores de ponta, como o meu iminente colega, o jurista Franklin Zimring, que produziu um estudo que deu brado sobre a política de "perpetuidade por dupla recidiva" na Califórnia, mostrando o absurdo jurídico e criminológico da lei dita "Three Strikes and You're Out". ${ }^{55}$ Nem um responsável político ou administrativo do Estado alguma vez se dignou consultá-lo sobre o assunto. E a Califórnia gasta oito milhões de dólares por ano para manter presos 170.000 condenados, três vezes o stock prisional da França...

Praticamente não existe lugar de discussão cívica e veículo organizacional adequado a fazer passar o trabalho científico para a esfera pública e a dar-lhe peso. Claro que há uma nebulosa de community organizations, mas elas ocupam uma posição marginal no campo burocrático - elas são mesmo, em minha opinião, um instrumento de domesticação da contestação política. Um outro obstáculo no caminho para a valorização cívica do trabalho científico são as

54 Visualizar o vídeo em http://utopiaconf.free.fr/video.htm.

55 Franklin E. Zimring, Gordon Hawkins e Sam Kamin, Punishment and Democracy: Three Strikes and You're Out in California (Nova Iorque, Oxford University Press, 2001). 
public policy schools e os think tanks privados que servem de verniz intelectual ou de "escudo" que protege os decisores políticos do pensamento crítico, produzindo um pseudo-saber pré-formatado, em todos os aspectos conforme aos interesses dominantes. ${ }^{56}$

Os campos político e mediático dos Estados Unidos são largamente controlados por interesses pecuniários, pelas grandes empresas e as grandes fortunas, que mantêm sob a sua dependência os dois partidos siameses, que mais não são do que etiquetas para facilitar a recolha de fundos e pagar as campanhas eleitorais que exigem passar por meios de comunicação que se fazem pagar. Dito assim, isto pode parecer caricatural, mas é a realidade que é caricatural: pense que todos os senadores sem excepção são milionários e que a campanha presidencial de 2008 vai custar cinco milhões de dólares! Na verdade, é toda a organização da esfera pública estadunidense que joga contra a implicação dos universitários na vida da Cidade, mas também a moral profissional dos investigadores que se vêem como academics mais do que como intelectuais (que cheiram a enxofre e amedrontam os deans).

É por isso que eu aproveito o facto de ter ligações profissionais e pessoais dos dois lados do Atlântico para vir regularmente à Europa, onde passo quatro a cinco meses por ano. Isso estimula as minhas energias e dá-me vontade de continuar o trabalho nos períodos de dúvida ou de cansaço. Tem-se tanto a aprender saindo da "academia" e ficando em contacto com pessoas que estão directamente implicadas no nível quotidiano, profissional, militante ou político, no coração dos fenómenos que se estudam... Em contrapartida, pode-se ajudá-los a ver a sua própria prática sob um ângulo novo e, por vezes, a focar melhor a sua acção.

\section{A CIÊNCIA SOCIAL COMO FAROL E COMO DISSOLVENTE}

SD Podem as suas pesquisas ajudar a guiar os militantes na sua acção?

LW Cabe-lhes a eles dizê-lo, ou descobri-lo, não a mim. Mas a actividade militante está cheia de armadilhas e de artimanhas que conduzem a um esbanjamento fenomenal de energias. Quando for esse o caso, é preciso ter a honestidade de dizer: "Alto, não é este o verdadeiro problema, está a perder o seu tempo". Pode ser este o papel do investigador.

Vejamos um exemplo preciso: nos Estados Unidos, os militantes pela justiça estão muito mobilizados contra a privatização das prisões e aquilo que a tese do "prison industrial complex" define como a exploração da mão-de-obra cativa dos detidos. Na realidade, o emprego prisional através de firmas privadas diz respeito apenas a 0,3\% dos prisioneiros: é um fenómeno absolutamente minúsculo. Batalhar pela abolição do "trabalho eclavagista" na prisão, é esgrimir contra 
uma quimera. E se amanhã se suprimissem as prisões comerciais nos Estados Unidos, o stock prisional permaneceria inalterado; ele seria simplesmente contabilizado nos $6 \%$ de celas a menos. Focalizando-nos na privatização, passa-se ao lado do essencial. Não é a busca do lucro capitalista que comanda a expansão impressionante da população aprisionada nos Estados Unidos, mas a construção de um Estado liberal-paternalista, quer dizer, um projecto verdadeiramente político que exige pensar em conjunto desregulação económica, restrição das ajudas sociais e expansão do sector penal. ${ }^{57} \mathrm{O}$ mesmo raciocínio vale para o que certos militantes de esquerda em França chamam ingenuamente "o programa securitário". Este programa só existe na imaginação deles: a segurança não passa de um logro que desvia o olhar da verdadeira questão em jogo, que é a redelimitação do perímetro e das missões do Estado face ao Moloch do mercado.

Idem pela Europa fora a propósito do pânico moral quanto à "guetização" das periferias populares: os militantes que se agitam para “desfazer os guetos" enganam-se no alvo. Os bairros marginalizados da periferia urbana da Europa estão nos antípodas do gueto. As suas populações estão misturadas e são cada vez mais etnicamente heterogéneas; as suas capacidades de organização colectiva vão diminuindo; as suas fronteiras são porosas, e são incapazes de produzir uma identidade colectiva, que não territorial e negativa. São anti-guetos que sofrem antes de mais de pauperização e do recuo generalizado do Estado. Em vez da "segunda geração da imigração", seria necessário tratar da terceira geração de desemprego em massa e da precariedade salarial crescente, que faz sobressair a discriminação porque o mercado de trabalho se retraiu e fragmentou. ${ }^{58}$

SD As suas análises transmitem por vezes a sensação sombria de que o mundo social é muito hermético e habitado por uma causalidade implacável. Para concluirmos: qual seria a sua mensagem de optimismo para o futuro das ciências sociais?

LW O sociólogo não tem de ser nem optimista nem pessimista; ele deve olhar de frente a realidade, com lucidez e utilizando todos os instrumentos que a sua ciência lhe põe à disposição. Ele deve apenas - mas é mais fácil dizer do que fazer! - ser rigoroso e intrépido na análise, para construir um modelo verdadeiro que permita identificar os pontos de intervenção e as alavancas possíveis de uma intervenção individual e colectiva. ${ }^{59}$ Se as minhas análises são

57 Loïc Wacquant, Punishing the Poor. The Neoliberal Government of Social Insecurity (Durham e Londres, Duke University Press, 2008); trad. portuguesa: Onda Punitiva. O Novo Governo da Insegurança Social (Rio de Janeiro, Editora Revan, 2007).

58 Loïc Wacquant, 2008, "Ghettos and anti-ghettos: An anatomy of the new urban poverty", Thesis Eleven, 94, pp. 113-1 18; trad. portuguesa em Cadernos de Ciências Sociais, no prelo.

59 Sobre a frente penal, ver: Loïc Wacquant, 2001, "L'avènement de l'Etat pénal n'est pas une fatalité”, Dedans-Dehors (Observatoire International des Prisons), 17 (Janeiro-Fevereiro), [continua] 
frequentemente sombrias e frias, isso é porque a época é sombria e fria! Não se trata de um traço de carácter do analista, mas de uma propriedade da realidade histórica. Agora, é claro que se se vê o mundo com os olhos dos dominantes, a paisagem social é muito mais rosa e entusiasmante!

Dito isto, as ciências sociais de hoje podem trazer uma contribuição cívica de primeiro plano, desempenhando o duplo papel de dissolvente e de farol. Dissolvente do novo senso comum neoliberal que "naturaliza" o estado actual do mundo e as suas tendências imanentes, pela crítica metódica das categorias e dos tópicos que tecem o discurso dominante. ${ }^{60}$ Trata-se aqui de dar ao maior número possível de cidadãos instrumentos de reflexão para se reapropriarem do seu próprio pensamento sobre o mundo social, para que não sejam pensados pelos média, possuídos pelas ideias pré-fabricadas que estes difundem em fluxo tenso, para que eles possam questionar os esquemas do debate político - de modo a porem em causa não apenas as soluções propostas mas o próprio diagnóstico dos problemas que a sociedade confronta. A ciência social também pode funcionar como um farol que esclarece as transformações contemporâneas, fazendo emergir da sombra propriedades latentes ou tendências despercebidas (um exemplo simples: a velocidade do crescimento do índice de Gini que mede a desigualdade dos rendimentos), e principalmente que revela possíveis laterais, pontos de bifurcação possível no avanço da história.

Contra a mitologia da "mundialização", nome suave que a revolução neoliberal se atribui, as ciências sociais podem e devem reinsuflar no debate público a ideia de que existem variações sociológicas muito significativas entre as sociedades contemporâneas, que são abusivamente apresentadas como uniformizadas e forçadas a alinharem todas no modelo da "sociedade de insegurança avançada" incarnada pelos Estados Unidos ou a sua sucursal prática e ideológica em que se tornou a Inglaterra. Estas variações são o resultado agregado de escolhas políticas que devemos fazer, não no escuro e às apalpadelas, mas à luz das ciências da sociedade, com pleno conhecimento de causa e de consequências.

Transcrição e primeira revisão de Elisabeth Coutant.

Pesquisa bibliográfica a cargo de Susana Durão.

Traduzido por Virgílio Borges Pereira e Maria Isabel F. Madureira Pinto.

[continuação] pp. 16-17; 2002, "Socialiser, médicaliser, pénaliser: un choix politique", Combats face au Sida. Santé, drogues, société, 27 (Março), pp. 4-9; 2004, "Comment sortir du piège sécuritaire”, Contradictions (Bruxelas), 22 (Dezembro), pp. 120-133. Sobre a frente urbana, ver: Loïc Wacquant, 2006, "Ghetto, banlieues, État: réaffirmer la primauté du politique,” Nouveaux regards, 33 (Abril-Junho), pp. 62-66.

60 "Critical thought as solvent of doxa", Constellations, 11-1, pp. 97-101. 